\title{
Changing Patterns of Chinese Policy-making on Regionalism
}

\author{
YANG JIANG
}

\begin{abstract}
China is increasingly active in regional cooperation, known as regionalism. This change has been catalyzed by the Asian financial crisis in 1997-98, supported by China's economic power and guided by national economic and political needs. Debates abound on whether China's rise is a threat or an opportunity for other Asian countries or for the world, although little research has been conducted on the policymaking for China's regional economic cooperation or economic diplomacy in general. This paper examines to what extent the trends of professionalization, corporate pluralization, decentralization and globalization (identified in Lampton 2001) from 1978-2000, exist in its policymaking on regional trade cooperation from 1978 to 2000. In this article, 'fragmentation' is used to integrate corporate pluralization and decentralization, as they are horizontal and vertical forms of fragmentation. This study therefore contributes to the understanding of China's 'post-WTO' foreign economic policy, economic diplomacy and its 'good-neighbour' diplomacy mulin waijiao.
\end{abstract}

Keywords: Regionalism, China, professionalization, fragmentation, globalization

\section{Introduction}

As countries in Asia debate whether China's rise is a threat or an opportunity, Beijing has gradually taken centre stage in the development of regional economic cooperation, leaving its neighbours little choice but to cooperate. Catalyzed by the Asian financial crisis in 1997-98 and guided by economic and political needs for domestic reform, China's participation in regional cooperation is no longer an attempt to export communism as in the pre-reform era, but a pursuit of pragmatic economic benefits and the image of a responsible great power.

Although China has established links with neighbouring countries in various areas such as the military, politics, trade and finance, it is trade that has achieved the most progress, reflected in preferential trade agreements and their forceful implementation. It is also an area that is closely associated with China's efforts at reform and opening, one that 
not only brings revenue but also has adverse impacts on domestic constituencies in China or those of its trade partners. Although China has also participated actively in East Asian financial cooperation, such as the Chiang Mai Initiative and its multilateralization, such cooperation still stays at a shallow level: China needs only to commit a certain amount of foreign reserves to the regional reserve pooling and does not have to bind itself in exchange policy or domestic financial reserves.

Therefore, this paper focuses on China's regional trade cooperation or trade regionalism, which takes the form of free trade agreements (FTAs). More specifically, it examines to what extent the trends of professionalization, corporate pluralization, decentralization and globalization in China's foreign and security policymaking during 1978-2000, as identified by authors in Lampton (2001), exist in its policymaking on regional trade cooperation. As China embarked on trade regionalism in 1999, when Premier Zhu Rongji proposed a free trade relationship to the Association of Southeast Asian Nations (ASEAN), and increased such activity significantly after China's accession to the World Trade Organization (WTO), this study contributes to the understanding of China's 'post-WTO' foreign economic policy and economic and 'goodneighbour' diplomacy mulin waijiao.

This paper is organized as follows: after a review of the existing literature, it assesses each of the above-mentioned trends in relation to China's regional cooperation policymaking before drawing some tentative conclusions on such trajectories to date and China's regional policy prospects in relation to domestic reform.

\section{Literature Review}

In international political economy, many studies attribute variations in trade policies and international economic cooperation to international factors, especially the global distribution of capabilities and international institutions. Fewer studies have examined the domestic sources of international cooperation, particularly in Asia (Milner et al. 2004; Ravenhill 2005). In China studies, there is a lot of analysis of China's foreign (economic) policy and regional diplomacy at the international level based on various theoretical premises of international relations (particularly realism and to a lesser extent constructivism) (e.g., Barnett 1967; Jacobson and Oksenberg 1990; Lieberthal and Lampton 1992; Robinson and Shambaugh 1994; Shirk 1994; Lardy 1998; Lu 2000; Reardon 2002). Very few address the domestic policymaking process (Fewsmith 
1999; Lampton 2001; Feng 2006; Kennedy 2005; Zeng 2007). Amongst them, a notable effort to open the black box is Lampton's edited volume (2001), in which a group of China experts identified trends in China's foreign and security policymaking from 1978 to 2000. They agree, to different degrees, that four general trends occurred: professionalization, corporate pluralization, decentralization and globalization.

Professionalization refers to the trend toward a higher level of specialized knowledge among Chinese decision-makers, the proliferation of expertbased bureaucracies and the increased reliance on specialized information. This learning curve is also documented by other scholars such as Woods (1993), Goldman (1999), Harris (2002) and Shambaugh (2002).

Corporate pluralization refers to the proliferation of organizations, groups and sometimes individuals in the policymaking process. This trend is widely acknowledged by scholars of China's economic policymaking, showing intensive bargaining and debates within and outside the policymaking circle. The politics of China's WTO accession is representative of such a pluralized policymaking structure (e.g., Shirk 1994; Harris 2002; Zweig 2002; Kennedy 2005; Feng 2006; Zeng 2007).

Decentralization is related to pluralization, but with more emphasis on the role of local governments. Decentralization of foreign economic policymaking power has been noted in various studies of China's reforms (Shirk 1994; Montinola et al. 1996; Yang 1996; Cheung et al. 1998; Breslin 2007: 61-70). Both corporate pluralization and decentralization are forms of fragmentation of the policymaking power, which is highlighted by theories of trade politics as well as a widely accepted model to describe Chinese policymaking - fragmented authoritarianism (Lieberthal and Lampton 1992). It remains to be studied how much fragmentation or authoritarianism exists in China's present-day making of regionalism policy.

Globalization refers to the effect of economic and information globalization on foreign policymaking as well as the increasing need to conduct multilateral negotiations. Other studies also show how increased global linkages of domestic actors have affected the power distribution and thinking of Chinese policymakers (Jacobson and Oksenberg 1990; Economy and Oksenberg 1999; Kent 2002, 2007).

Despite abundant evidence of these four trends in Chinese foreign policymaking, existing studies differ on the degree of change, since it depends on the policy area and historical context. To date, little research has been conducted on the policymaking of China's regional economic cooperation or economic diplomacy in general. Foreign economic policymaking after the WTO accession remains understudied as well 
(except Zeng 2007, which focuses on trade disputes at the WTO). This paper fills this gap by examining the extent to which professionalization, fragmentation and globalization have taken place in the policymaking of China's trade regionalism (used interchangeably with FTAs, according to the definition of regionalism by the WTO).

\section{Professionalization}

Chinese trade policymakers have gained experience, skills and knowledge not only from multilateral negotiations at the WTO, but also from participating in regional cooperation in the past decade. They have also come to rely increasingly on expert opinions and outsourcing studies.

When China started the first FTA talks - the China-ASEAN FTA, or CAFTA - the Ministry of Foreign Affairs was the lead agency in China's negotiation team because the talks were regarded as part of China's good neighbour diplomacy. The experts from the Chinese Academy of Social Sciences (CASS) and the Institute of Foreign Trade and Economic Cooperation (IFTEC, a think tank affiliated with the Ministry of Foreign Trade and Economic Cooperation or MOFTEC, which later became Ministry of Commerce or MOFCOM) were invited to participate in the feasibility study. To both groups of experts, the CAFTA was not the most rational agreement for China to pursue because of the limited market potential in ASEAN for Chinese products, but they had both been proponents of Asian regional integration in track-two dialogues and hoped the CAFTA could serve as a first step in regional integration in East Asia (personal interviews with CASS and IFTEC researchers, Beijing, 2006 and 2007). The resulting feasibility study therefore emphasized potential mutual benefits, without specific prediction of the implications for domestic sectors, which later turned out to be challenging for some producers in both China and ASEAN countries.

However, during the implementation of the CAFTA and negotiations of other proposed FTAs, Chinese policymakers gained experience with negotiating bilateral trade cooperation and received more political pressure to protect domestic interests, as will be discussed later. Although FTAs are still an important part of China's economic diplomacy, MOF$\mathrm{COM}$ is by default the lead agency because China needs to conduct commercially meaningful dialogues with its foreign counterparts, which are all foreign trade agencies.

Chinese policymakers have realized that foreign economic policymaking should be sophisticated and 'scientific', that is, that policymakers 
should know about the potential costs and benefits of a policy for the domestic economy. They realized that some domestic interests would have to give way, if necessary, when they conflicted with the national interest as defined by top policymakers. Therefore they try to assess the economic implications of proposed FTAs before they go into negotiation to maximize China's economic benefits. As its bureaucratic capacity is stretched, MOFCOM often commissions think tanks (such as CASS, IFTEC, the Development Study Centre of the State Council and the Institute of International Economic Relations at the National Development and Reform Commission, or NDRC) and universities (for instance Nankai University, Chinese Agriculture University, University of International Business and Economics) to carry out the feasibility studies. The policymakers explain that academics are invited into the domestic consultation process because they are not biased by the narrow interests of domestic industries or provinces, and that their views are theoretically informed (personal interviews with MOFCOM officials, Beijing, April to May 2006). It is also noticeable that the government has expanded the circle of academic institutions involved in the policymaking process, from a couple of quasi-governmental think tanks in the earlier cases to include research institutes in provinces, in particular when their opinion is needed on the impact on local economies. For instance, MOFCOM consulted with researchers in Yunnan, Guangxi and Hainan provinces about the impact of the CAFTA on local tropical fruit producers during its implementation and researchers from Xinjiang, Fujian and Hubei were invited to a conference in 2006 to discuss implications of the proposed Australia-China FTA (AUCFTA) on agriculture.

Trade policymakers with more experience in international negotiations have also been appointed to carry out difficult FTA bargaining. The Department of International Cooperation at MOFCOM usually has the key responsibility; however, for negotiations that need specialized knowledge and superb negotiation skills to avoid significant negative impacts on domestic economy, such as the AUCFTA, the WTO Department is appointed for their experience at WTO negotiations. It is likely that it will also carry out future FTA negotiations with some other developed economies.

In contrast to the centralized and secretive process of the CAFTA policymaking, MOFCOM now collects opinions about proposed trade agreements from industries (through industry-line ministries and industrial associations) and local governments through written or online questionnaires, as is the usual practice in other countries. This practice 
in effect pluralizes the policymaking structure by inviting more actors to participate, but also underlines the effort of Chinese trade policymakers to make informed decisions. At the same time, it takes some time for domestic constituencies to make informed assessments and to get used to this way of expressing interests. The awareness of FTAs has increased among Chinese companies but the usage of these channels to express opinions is still low (personal interviews with MOFCOM officials, Beijing, 2007). The information provided by government agencies has not always been consistent, to the embarrassment of trade negotiators and frustration of their foreign counterparts (Drake-Brockman 2006). This inconsistency was also shown in statistics from various government agencies during the current global financial crisis, which prompted Beijing to include an article in the draft amendment to the Statistics Law in June 2009 that government agencies should not publish any information that differs from information from the National Statistics Bureau.

The content of regional economic cooperation has become so complex today that in many cases its policymaking is a process of mutual learning and concerted agenda-setting between partner countries. If carried out thoroughly, regionalism is not traditional barter trade of concessions anymore but a 'systematising of knowledge and principles' (Kent 2002; Huang 2003). In other words, it can provide an incentive for the parties to streamline their domestic procedures to reduce transaction costs and close policy loopholes. The proposed AUCFTA had the potential to align China's policymaking institutions on behind-the-border issues with those in a market economy and Australia requested China to do so to guarantee the benefits Australian companies could reap from the FTA. Before the two countries exchanged substantial offers and requests, they had gone through a lengthy process of familiarization with each other's domestic systems. The Chinese government and businesses regarded Australia as a developed country with advanced regulations for a market economy and expressed their willingness to learn from Australian practices if conditions allowed. Although domestic regulators have so far resisted systematic change, they have gained a lot of knowledge on the operations of a market economy during the process of negotiation. For instance, the Chinese government tried to include a clause in the AUCFTA to stipulate the pricing and supply of energy resources from Australia to China to secure a 'stable supply'. After a process of dialogues and negotiations, Chinese policymakers have accepted that such a clause is not usually included in FTAs, in particular for a market economy like Australia. China therefore has sought to lock 
in an energy supply through other means, such as aggressive company investments and energy diplomacy. China also agreed to include a separate chapter on Intellectual Property Rights (IPRs), which is extremely important for foreign investors. Although the negotiations on this FTA have stalled, this process has familiarized China with how to negotiate an FTA with a developed country, and forced China to reflect on its domestic regulations, especially those not completely in accordance with its WTO commitments.

\section{Fragmentation}

Various domestic interests, to different degrees, have influenced the state's decision regarding regionalism, sometimes significantly limiting the state's autonomy to pursue national interests. It is found that partial reform in China has strengthened the political power of protectionist forces vis-à-vis liberalizing ones, and policymakers' concern over social instability constrains China's capacity to make offers or compromise in trade negotiations. The form of fragmentation can be roughly divided into horizontal-among agencies representing industries and sectors at the national level-and vertical-between the central government and local governments.

\section{Horizontal Fragmentation}

In the case of China's first FTA, the CAFTA, policymaking was quite centralized. It was proposed by Premier Zhu Rongji, with few domestic actors knowing in advance. Zhu's strong commitment continued to propel the policymaking process on the CAFTA during his tenure because few officials in China would dare to openly challenge the authority of the leadership. After initiation, the decision-making power was allocated to the Ministry of Foreign Affairs (MFA), which was insulated from domestic economic actors -including industries and local governments - and commanded high authority in China's diplomacy formulation. After the Framework Agreement was signed, the decision power was allocated to MOFTEC to 'implement' that agreement, which actually meant formal FTA negotiations. At this stage, MOFTEC did not enjoy as much insulation as MFA had, because MOFTEC had equal status with other industrial ministries and with local governments and had a working relationship with them on economic matters. As the lead agency and policy coordinator, MOFTEC convened working meetings with relevant ministries and provincial governments to hear their views. 
Still, because the CAFTA was China's first FTA with another country, domestic industrial sectors and local provinces were not familiar with its implications. A survey conducted by the China-ASEAN Business Association in 2003 showed that 97 percent of Chinese companies did not know of the existence of the CAFTA or the meaning of FTAs (personal interview with the Director of the China-ASEAN Business Association, April 2006). Even though some had concerns over the potential costs to agriculture, they were silenced forcefully by the Premier and trade policymakers at secretly-held meetings, or they kept quiet because they were aware of the strong political message behind it. Importantly, MOFTEC had the power to report directly to the State Council if there was any difficulty in coordinating domestic interests (personal interviews with MOFCOM officials and scholars involved in the policymaking process, Beijing, March to May 2006).

However, domestic actors are becoming increasingly vocal about their particular interests. Although Chinese 'interest groups' do not take the same form as lobby groups or independent industrial associations in Western countries, domestic actors compete and express their preferences through industrial-line ministries, national commissions or local governments. As predicted by the Ricardo-Viner model of trade (Hiscox 2001), export-oriented industries in China, such as labour-intensive manufacturing sectors, are supportive of trade liberalization under FTAs while import-competing industries are against it, such as agriculture in most cases and services in the FTA negotiations with developed countries such as Singapore and Australia. Agriculture and several other service industries, such as telecommunications, banking, transportation, legal services and construction, have their respective ministries or national commissions; foreign investment policies are under the NDRC.

Reform has only been partial in these sectors and the government agencies in charge of these sectors have retained significant regulatory power; any further reform needs their consent. That is not only because the making of industrial policies in China is fragmented among these ministries and commissions, but also because faithful implementation of policies largely depends on the determination of these ministries and local governments. These agencies would like to retain their power over the national economy, and for some, to retain the rents for the bureaucracy generated from such power and the huge profits for the sector from administrative monopoly. Therefore, further liberalization has been difficult to realize in the above-mentioned industries, not to mention through regional trade agreements. 
Although MOFCOM is usually designated as the lead agency in China's FTA policymaking, it only has the authority of a negotiator on behalf of industries, not the authority of a coordinator. In other words, MOFCOM is expected to represent the interests of industries at international negotiations, and thus their proposals for the negotiation agenda need the endorsement of relevant industrial ministries or national commissions, which is often very difficult to achieve. Unlike the case of the CAFTA or the WTO accession, MOFCOM is not expected to rely on the State Council any more to solve problems in domestic coordination. As a result, domestic interest groups in the aforementioned sectors are assertive in resisting further liberalization beyond the WTO levels, as long as the political leadership does not directly intervene in the policymaking process.

Partial reform in China has not only created rents for regulators of agriculture and services, as theorized by Hellman (1998), but also provided protectionists with reasons for opposing further liberalization, drawn from painful experiences without acknowledging possible benefits during past liberalization, as was the case for agriculture in both the CAFTA and AUCFTA policymaking. Some sectors resist further trade liberalization, citing the adverse impact of WTO on domestic producers. The above-mentioned service industries claim that they are still monitoring the impacts of the enforcement of WTO commitments at the end of 2006 and are not willing to take any further risks. One lesson some Chinese domestic actors have learned from the WTO membership is that opening the economy to competition does not necessarily enhance the productivity of agriculture. Besides, the Chinese government has been pushing for a self-sufficiency policy that seeks to ensure China is 95 percent self-sufficient in grains, to guarantee China's food security. The domestic agricultural sector uses that lesson and food security as excuses to avoid further opening the agricultural market under FTAs where possible. The interests of farmers are represented by the Ministry of Agriculture because there is no farmers' union or organization in China, and the Ministry, like that in most other countries, is protectionist for its own reasons - career prospects for officials and profits from existing rents for the bureaucracy.

Whether the reduction of tariffs would make a real difference to the life of farmers, agricultural issues were indeed very sensitive in China. 'Constructing a harmonious society' is the overarching social and political objective of the Hu-Wen government. An official of MOFCOM commented that it was remarkable that the leadership publicly acknowl- 
edged that social problems were pressing in China and that it showed how important these issues were to the leadership (personal interview, Beijing, May 2007). The incidence of peasant protests has been on the rise in recent years and therefore the government put solving problems with 'three agricultural' issues - peasants, rural area, and agricultural production - on the top of the list for government policies at the sixteenth National People's Congress.

MOFCOM officials are in general proponents of reform and liberalization, believing competition enhances productivity and free trade benefits consumers. However, they have taken a cautious position on agricultural trade in the FTA negotiations after the 'Early Harvest Programmes' in the FTAs with ASEAN and with Pakistan. In the FTA negotiations with Australia, Chinese trade negotiators have insisted on the sensitivity of agricultural issues in Chinese domestic politics and resisted concessions in this sector. China has also dismissed the request from developed countries for China's further liberalization of agriculture at the Doha Round of WTO negotiations on the grounds of being a 'newly-admitted member'. Now Chinese trade policymakers regard agriculture as a special and sensitive sector for every country because of political reasons, as has been well demonstrated at the WTO negotiations, and that therefore it is natural that countries would not compromise their domestic interests in an FTA. MOFCOM notes that agriculture is widely protected by developed countries because of historical experiences. It is a question, it thinks, for China to consider whether it should follow the path of developed countries - to significantly shrink the agricultural sector and protect what remains with tariffs, quotas and subsidies (interviews with Chinese negotiators from MOFCOM, Beijing, April 2006 and May 2007). This shows a nuanced development in Chinese policymakers' view towards the agricultural sector, from one that was determined to reduce agricultural population even at the expense of domestic interests, to a more reflective and cautious attitude towards the policy objective and the ways to achieve that.

Compared with the previous generation of leadership, the Hu-Wen leadership is under more domestic pressure to care for social welfare because social tensions have escalated and become more open, which casts doubt on the government's previous reform and liberalization programmes. In a political environment that increasingly stresses social welfare and 'scientific development' vis-à-vis purely economic growth, the Chinese state has to pay more attention to the losers. It is known that politics among factions and power sharing within the Chinese elite, 
in particular between the reform-minded and the 'new left', have been crucial factors in shaping Chinese domestic politics (e.g., Dittmer and Liu 2006; Hook 2007; Bo 2007). Moreover, as a major channel where various domestic actors express their opinions, the National People's Congress (NPC) has evolved from merely a 'rubber stamp' to a stronger power centre in China's domestic politics. Traditionally only a venue to discuss domestic issues, the NPC has raised concerns about the impacts of foreign economic policy, including FTAs, on local economies. They have submitted formal bills to investigate the problems within a sector caused by certain foreign economic policies, and MOFCOM has had to respond and explain such issues to the NPC at special hearings (interviews with MOFCOM officials, Beijing, May 2007).

\section{Vertical Fragmentation}

The power distribution between the central government and local governments in China has gone through several periods of decentralization and recentralization (Shirk 1994; Branstetter and Lardy 2006). As will be discussed in the next section, the WTO membership has been a means through which the central government imposes trade liberalization upon industrial sectors and local governments and thus the process of WTO accession and implementation may imply recentralization. However, the Chinese government does not regard regionalism as an instrument to impose liberalization. Only when political pressure from the central leadership was strong were local governments compelled to compromise their own interests, as was the case in the CAFTA policymaking. However, heightened sensitivity in Beijing over social instability has to some extent empowered local governments as they become more assertive of their interests. They sometimes resist liberalization and sometimes are willing to sacrifice some local producers to reap the benefits in other sectors that FTAs may bring.

In the case of the CAFTA, even though an increasing level of assertiveness could be seen in provinces that were adversely affected, overall they kept their voices low. Local governments were not involved in making policies on the CAFTA because Beijing expected them to implement policies set by the central government or to revise local regulations if inconsistent with the central policies. They could report problems or seek the support of industrial ministries if problems occurred, but they were not invited to the policymaking working meetings organized by the MOFCOM.

The CAFTA has mostly affected the economy of provinces like Yunnan and Guangxi, which produce tropical agricultural products. The 
provinces therefore decided to 'encourage' (expand and strengthen) the industries with comparative advantage (such as temperate produce and manufacturing), and to 'discourage' (reduce or shrink) those with comparative disadvantage with ASEAN, including tropical plants, fruits, rubber, sugar, synthetic fibres and fertilizers (Wan 2006; Wang 2006)

Concerned Chinese government agencies, including the Ministry of Agriculture and the local government of Guangxi province, submitted internal reports to MOFCOM regarding the negative effects. The MOFCOM responded that they should look at the big picture and consider national interests. In the view of trade policymakers, first, China should 'calculate the total balance sheet' of trade instead of focusing on the costs in only agriculture, because the FTA would eliminate tariffs across all sectors (personal interviews with MOA, MOFCOM and Guangxi officials, Beijing and Nanning, April to June 2006).

The CAFTA has also provided the local governments with opportunities to engage in activities alongside the FTA beyond what they used to be able to do. Because Yunnan and Guangxi were 'sacrificed' in the Early Harvest Programme, which led to a drastic increase in imported tropical produce from ASEAN, the central government compensated Yunnan with a Kunming-Myanmar road and hydropower stations, and Guangxi with the China-ASEAN Trade Expo. The background to these two policies was that the central government had been stating that the CAFTA would bring economic opportunities to enliven the economy of West China. Local Chinese officials understood that such opportunities would usually include the support of the central government for their economic development with special policies. In fact, Yunnan and Guangxi have competed in requesting that the central government champion them in expanding economic relations with ASEAN under the CAFTA. Both provinces are promoting themselves as the best location for doing businesses between China and ASEAN. Guangxi aimed to be the axis of 'one axis, two wings' (referring to the Pan-Beibu Gulf and Great Mekong Sub-region as two plates and Nanning-Singapore economic corridor as an axis, which forms the shape of the letter $\mathrm{M}$ ) and requested the central government make it the experimental area of the CAFTA. At the same time, Yunnan hoped to be the 'dragon's head' of the Great Mekong Sub-region and the centre of a Great M transportation network between China and ASEAN (He et al. 2003; Ren 2006).

The idea of holding the China-ASEAN Expo in China was actually proposed by Yunnan to the central government. Accepting it as a good idea, the central government decided to give the opportunity to Guangxi 
instead. It was believed in the two provinces that Guangxi was more successful than Yunnan in 'persuading' the central government that it was a better location - it not only has a land border with ASEAN, but also sea ports. Others believe that the centre also took into account that Guangxi used to be a base for the Communist revolution before 1949, but the economy lagged far behind Guangdong's because of the government's preferential policies given to the latter, although the two have similar geographical conditions (personal interviews with Yunnan and Guangxi officials, Kunming and Nanning, June 2006). Besides, Yunnan had already become the major participant in the Great Mekong sub-regional development project, supported by the Asian Development Bank and the Chinese government and it hosted a Kunming Trade Fair every year. As a result, the China-ASEAN Expo was permanently located in Nanning, the capital city of Guangxi province. Since the first Expo in October 2005, a 'conference economy' has boomed in Nanning, including the construction of hotels, roads and conference sites and other services. As the Guangxi government had hoped, the Expo has brought numerous investments and business contracts from Southeast Asia.

Overall, the discourse and attention in China's southern provinces have been turned to the benefits and opportunities brought about by the CAFTA, mostly for the local governments and companies. Costs and challenges have been underplayed and shouldered by farmers. The competition between Yunnan and Guangxi provinces for preferential policies or the opportunity to serve as the locality to promote China-ASEAN economic cooperation has made it even harder for local governments to complain about costs.

During the negotiations of the AUCFTA, as discussed previously, the provinces that might have been affected by the AUCFTA were more vocal than Guangxi and Yunnan in the CAFTA case, particularly those with a significant number of ethnic minorities (Xinjiang, Gansu, Ningxia and Inner Mongolia). They include Muslims and Mongolians, most of whom rely on cattle farming for a living, while Australia is strong in farm products (meat and dairy products). At a bilateral conference on FTA agriculture issues in Xi'an in September 2006, a researcher from the Xinjiang Uygur Autonomous region advised the Chinese government to open wool trade gradually so as to avoid adverse impacts on Chinese fine wool growers, which was essential to 'protect the ethnic minorities' economy and maintain the border stability' (Tian 2006). Because ethnic issues have become more sensitive in recent years in China's domestic politics, with increases in the number of violent conflicts between the 
Han majority and Muslims (Moneyhon 2004; Koch 2006), Beijing is very careful with any policy that would adversely affect ethnic minorities. Due to concerns both over agricultural and ethnic issues, China has stood firm in protecting agriculture in the FTA negotiations with Australia.

The above discussion shows that on the whole, local governments are not as closely involved in FTA policymaking as industrial ministries or national commissions. This shows that Beijing still regards regionalism as diplomacy and cooperation between national governments, although it takes into consideration local interests if they are considered to be directly linked with social stability.

\section{Globalization}

In Lampton (2001), although globalization of policymaking essentially includes any process of internationalization, it puts great emphasis on the need to engage in multilateral negotiations on a global scale. The discussions so far show that FTA policies have in different ways affected domestic actors, and Chinese policymakers have to consider and deal with such impacts. Besides, international learning has been an important factor in both professionalization and fragmentation. The information on China's trade negotiations is more transparent than in earlier years during the WTO accession thanks to globalization of information, although domestic coordination remains largely secretive. The remaining important question is: in actively pursuing regionalism, has China forgone multilateralism once it attained WTO membership and adopted bilateralism and regionalism instead as the major means of international economic cooperation? The answer can be found in Chinese policymakers' perspectives on the functionality and legality of FTAs as well as China's practice in deciding the forms of its FTAs.

\section{Functionality}

China holds that FTAs and the WTO are not contradictory but complementary to each other, and it will 'walk with both legs' (MOFCOM 2007). As to the timing of the start of China's activism in FTAs, Chinese officials explained that because WTO accession negotiations with major members had been finished - with the US in 1999 - the government had more bureaucratic capacity to consider policies on regionalism. Besides, they did not need to worry anymore that regional initiatives would jeopardize China's WTO membership (interview with a MOFCOM official, Beijing, April 2006). There are 
certainly more specific reasons for China's first FTA proposal, the China-ASEAN FTA (CAFTA); the foremost one is that China tried to allay ASEAN's worry about China's economic threat upon its accession into the WTO (interviews with trade officials and scholars, Beijing, 2006; Zhang and Zhou 2003: 14).

Chinese trade policymakers argue that the multilateral trade regime cannot completely replace regional economic organizations in promoting trade and economic development between regional members. They list the slow progress at the WTO as one of the reasons for China's interest in FTAs. They note that the process of the Doha round of negotiations is very slow and difficult, while trade liberalization among a small group of countries is easier to negotiate. Besides, areas not covered by the WTO may be included in FTAs. The Framework Agreement between China and ASEAN covers five areas for cooperation, some of which go beyond the WTO to include technology and development cooperation, and as mentioned earlier, China has sought to include a stable energy supply in the FTA with Australia. China believes that 'we should fully utilize the greater flexibility of FTAs so that we can deal with specific problems more easily' (Xu et al. 2003: 145; Zhang and Zhao 2003: 20-22). Especially when the WTO accession did not bring about the expected growth rate of exports because of non-tariff barriers and trade disputes, Chinese policymakers became determined that China needed to look for alternative, short-term strategies to expand trade.

Multilateralism and regionalism serve different objectives for China's international strategy. Multilateralism is used for pursuing China's global economic interests, gaining access to global economic rule-making, and building China's international image as a responsible great power. As with other big powers, China is fully aware of the importance of global trade and multilateral institutions. A major force behind China's determination to join the WTO was to end the uncertainty in receiving the MFN treatment from other countries, which not only limited China's exports, but also hurt its national pride when the MFN treatment was associated with human rights. The WTO accession was imperative to the Chinese leadership, despite costly domestic reforms, because in domestic discourse it was closely linked with China's national pride as a great power that deserved equal trading rights as enjoyed by most other countries, the international recognition of China's reform efforts to build a market economy, and the government's (including leaders like Jiang Zemin and Zhu Rongji) competency in international negotiations. Such an imperative is lacking in China's FTA endeavours. 
Regionalism is used for China's pragmatic and strategic objectives, including establishing rules in bilateral and regional relations. Having experienced 15 years of hardship in applying to join the WTO, China has realized the significance of being part of rule-making in international institutions. Chinese scholars think that 'if the most important thing of China's entry into the WTO is to obey the rules of the game, the negotiations of CAFTA will be the start of China in making the rules of the game' (Xu et al. 2003: 163; also see Zhang and Zhou 2003: 129-31; Zhang and Zhao 2003: 14). It means China would not only make rules in bilateral relations, but also gain power in global arenas through the voice of a group.

\section{Legality}

Chinese trade policymakers are aware that 'FTAs are exceptions to the Most-Favoured-Nation (MFN) treatment of the WTO' (MOFCOM 2006), but they argue that FTAs are legal under the WTO and have become a common practice by other countries. Beijing has also highlighted the proliferation of FTAs in the world since the 1990s as it explains China's move into regionalism. In particular, China cites the examples of the EU and NAFTA and the FTA talks between the EU or the US with Asian countries 'at China's doorstep'. Chinese policymakers regard the development of FTAs as a 'historical trend', just as globalization, and as a new form of international competition after the Cold War. They hold that FTAs are exclusive-FTA partners do not give the preferential treatment to other countries - and if China did not 'advance with the trend of the era' and participate actively in regional economic cooperation, it would lose overseas markets and other opportunities (MOFCOM 2007; Xu et al. 2003: 30; Zhang and Zhou 2003: 103-05).

Many Chinese policymakers state that the WTO explicitly acknowledges the legality of FTAs. When Beijing was considering Hong Kong's proposal of an FTA with the mainland, Chinese Vice Minister of MOFTEC, Long Yongtu, commented that the establishment of such an area was totally in line with the WTO regulations. This view was supported by Mike Moore, then Director General of the WTO, who cited the examples of the EU and NAFTA (People's Daily 2001).

Trade negotiators suggest that China can quote Article XXIV of the GATT, Article V of GATS or the Enabling Clause for the legitimacy of China's FTAs, depending on the nature of the agreement and the partner country. For instance, China could either quote Article XXIV or the Enabling Clause for the FTA with ASEAN, although it eventually used 
the latter because of ASEAN's preference (personal interview with a trade official, Beijing, May 2006). Under the Enabling Clause, as Chinese policymakers believe, China does not have to make sure its FTA with another developing country is a comprehensive single undertaking, and China does not have to liberalize trade to the same extent as its partner country in agreements that involve an industrialized economy (personal interview with MOFCOM officials, Beijing, May 2007). When asked if they were concerned that Article XXIV of GATT requires the FTAs to cover 'substantially all trade', Chinese policymakers interpreted this requirement as 'FTAs should try to liberate as much trade as possible'. At the same time, they pointed out that few FTAs in the world were really free (personal interview with Chinese officials, Beijing, 2006 and 2007; for discussions on Article XXIV and the WTO rule over regionalism, see WTO 2000; Mathis and Bhagwati 2002; Matsushita 2004).

\section{Practice}

Since all FTAs that WTO members enter into should be reviewed by the WTO on their compatibility with the trade rules, has China tried to keep its FTAs compliant with the WTO rules during FTA negotiations?

First, China prefers a selective, gradual approach to trade liberalization under the FTA rather than a comprehensive 'single undertaking'. An exception may be found in the Closer Economic Partnership Agreement (CEPA) with Hong Kong. The MOFCOM admitted that the negotiations were not easy because it had to cover wide areas according to the WTO requirement while taking into account the possible impacts on mainland industries (CASS 2003). It is understandable that China had this awareness because it was the first FTA China was involved in and therefore was careful to obtain the WTO's approval. However, China does not regard CEPA as a real FTA because Hong Kong is part of China, which was why the name was changed from FTA to CEPA. Still the CEPA is a 'living' agreement, to which new contents are gradually added. The FTA with New Zealand covers trade in goods, services and investment, but the range of sectors in services and investment is very limited.

In all other FTAs, China has preferred to negotiate trade in goods first and trade in services and investment later. The Early Harvest Programmes with ASEAN and with Pakistan only included a narrow range of goods and Chinese policymakers proudly called it an excellent 'innovation' by China to give its partner confidence in the benefits of the prospective FTAs (Shang 2005). Even for the final agreement on trade in goods, China prefers to exclude a wide range of sensitive products and 
seems very understanding if the partner would like to do so as well. As a result, ASEAN, Pakistan and Chile all excluded a long list of products. The agreement on trade in services with ASEAN excludes many sectors that Singapore has an advantage in.

Second, China prefers gradual implementation of FTAs. The FTA with ASEAN takes a long 'phase-in' period to realize -10 and 15 years respectively for ASEAN's more and less developed members.

Third, China is also reluctant to include 'behind-the-border issues' in FTAs. Problems in intellectual property rights and transparency, Beijing argues, cannot be solved overnight in China. China holds the position that it has been trying its best to realize its promises to the WTO, and therefore would not make systemic or regulatory changes under an FTA.

Finally, China does not aim to forge its bilateral FTAs together to form multilateral arrangements. In Asia, it has been comfortable with forming bilateral agreements such as the ones with ASEAN, Thailand, Singapore and South Korea, but it is suspicious of the plausibility of a Northeast Asia FTA or East Asia FTA, even though it proposed the former to show goodwill to its neighbours. China holds that this is mainly because of historical problems with Japan, as well as Japan's protective stance in trade. An FTA in the Asia Pacific is regarded more unlikely given its wide coverage. China does not plan to have FTAs with the US or EU and does not think the latter two would consider an FTA, for strategic and economic reasons. Moreover, unlike the US, China does not have a template for its FTAs. China's FTAs take various forms in terms of tariff levels, reduction of non-tariff barriers, and Rules of Origin (RO). For the Rules of Origin in China's FTAs, usually a product is eligible for preferential concessions only if at least 40 percent of its content is locally produced (in the FTA with ASEAN, Chile and Pakistan). It has recently agreed in principle to Australia's proposal that the AustraliaChina FTA use the change of tariff classification for the RO. Like many other existing FTAs in the world, China's FTAs could contribute to the 'spaghetti bowl' effect on international trade.

However, whether it is intended or not, there is still hope that China's FTAs can contribute to multilateral trade liberalization. First, because China regards regional groups as a platform to raise its voice at global arenas, China may use its increasing influence to push forward the WTO negotiation process, while making concessions needed on its part. Second, although Chinese negotiators are reluctant to give concessions on protectionist domestic industrial sectors and societal pressures increasingly decide what form China's FTAs take, it is still possible for the 
leadership to intervene in the negotiation process for political reasons and to enforce liberalization, in cases where such concessions are judged not to threaten domestic social stability. Such concessions are usually on a small scale, such as those in China's FTAs with ASEAN, Pakistan and New Zealand, but the resulting increased market competition may in fact prepare China better for liberalization on a global scale.

\section{Conclusion}

This study shows that in the making of China's regionalism policies up to 2000, the trends of professionalization and fragmentation identified in Lampton (2001) have continued in the 'post-WTO' era, while the record on globalization has been mixed. To be more specific, Chinese officials have gained negotiation skills and knowledge about market economy and bilateral trade cooperation and the government increasingly invites experts and businesses into the decision-making process. Horizontal fragmentation of power at the national level has intensified among MOFCOM, industry-line ministries and national commissions, making coordination difficult for trade negotiators. Vertical fragmentation between central and local governments has occurred but to a lesser degree, as regionalism is an important part of Chinese state diplomacy and local governments can sometimes afford to sacrifice some local producers to take advantage of opportunities. As for globalization, regionalism for China is a means to deal with the drawbacks in globalization and thus may delay the process of multilateralization; at the same time it provides a platform for China to prepare itself better for global integration and to gain influence in multilateral institutions.

China's regionalism policy and domestic reform are closely related to each other. Markets needed for Chinese exports as well as political pressure from the international environment prompted China to embark on trade regionalism in the form of FTAs, and Beijing will continue to engage actively in various forms of regional cooperation for both political and economic gains. Economic reform and liberalization on the one hand have prepared China for signing such binding agreements, and on the other hand have empowered some domestic protectionist forces vis-àvis liberalizing ones, especially after the WTO accession. As the Hu-Wen government emphasizes 'harmonious society' and 'scientific development' instead of pursuing purely economic growth or national political interests, China will continue to be pragmatic in maximizing economic benefits and cautious with what concessions it makes in regional cooperation. 
Yang Jiang is an Assistant Professor at Asia Research Centre, Copenhagen Business School. (yj.int@cbs.dk)

\section{REFERENCES}

Barnett, A. Doak 1967. Cadres, Bureaucracy, and Political Power in Communist China. New York: Columbia University Press.

Bo, Zhiyue 2007. China's Elite Politics: Political Transition and Power Balancing. Singapore: World Scientific.

Branstetter, Lee and Nicholas Lardy 2006. 'China's Embrace of Globalization.' NBER Working Paper Series 12373: 3-56.

Breslin, Shaun 2007. China and the Global Political Economy. New York: Palgrave Macmillan.

CASS 2003. 'CEPA: Yuanqi, Yiyi Ji Yingxiang' [CEPA: Origin, Nature and Implications]. The Pursuit of Economic Trends 48, 388 (8 July)

Cheung, Peter T.Y., Jae Ho Chung and Zhimin Lin (eds) 1998. Provincial Strategies of Economic Reform in Post-Mao China. Armonk and London: M. E. Sharpe.

Dittmer, Lowell and Guoli Liu 2006. China's Deep Reform: Domestic Politics in Transition. Lanham: Rowman and Littlefield.

Drake-Brockman, Jane 2006. 'Chinese Approaches to Negotiation: Implications of Contemporary Practices for the Future.' The China's Future Diplomacy Research and Public Symposium, Canberra, 3-4 July.

Economy, Elizabeth and Michel Oksenberg 1999. China Joins the World: Progress and Prospects. New York: Council on Foreign Relations.

Feng, Hui 2006. The Politics of China's Accession to the World Trade Organisation: The Dragon Goes Global. London and New York: Routledge.

Fewsmith, Joseph 1999. 'China and the WTO: Politics Behind the Agreement.' NBR Analysis 10, 5 (December): 23-39.

Goldman, Merle 1999. 'The Emergence of Politically Independent Intellectuals.' In M. Goldman and R. MacFarquhar (eds) The Paradox of China's Post-Mao Reforms. Cambridge, Mass.: Harvard University Press: 283-307.

Harris, Stuart 2002. 'Globalisation and China's Diplomacy: Structure and Process.' Working Paper. Canberra: Department of International Relations, Australian National University.

He, Shengda, Xuehong Wang and Zhankui Gong (eds) 2003. Zhongguo-Dongmeng Ziyou Maoyiqu Jianshe Yu Yunnan Mianxiang Dongnanya Kaifang [The Construction of the ASEAN-China Free Trade Area and Yunnan's Opening to Southeast Asia]. Kunming: Yunnan People's Press.

Hellman, Joel S. 1998. 'Winners Take All: The Politics of Partial Reform in Postcommunist Transitions.' World Politics 50, 2: 203-34.

Hiscox, Michael. J. 2001. 'Class Versus Industry Cleavages: Inter-Industry Factor Mobility and the Politics of Trade.' International Organization 55 (Winter): 1-46.

Hook, Leslie 2007. 'The Rise of China's New Left.' Far Eastern Economic Review (April): 8-14.

Huang, Yasheng 2003. Is China Playing by the Rules? Free Trade, Fair Trade and WTO Compliance. Report submitted to the US Congressional-Executive Commission on China.

Jacobson, Harold K. and Michel Oksenberg 1990. China's Participation in the IMF, the 
World Bank, and GATT: Toward a Global Economic Order. Ann Arbor: University of Michigan Press.

Kennedy, Scott 2005. The Business of Lobbying in China. Cambridge, Mass.: Harvard University Press.

Kent, Ann E. 2002. ,China's International Socialization.' Global Governance 8, 3 (JulySeptember): 343-64.

- 2007. Beyond Compliance: China, International Organizations, and Global Security, Studies in Asian Security. Stanford, Calif.: Stanford University Press.

Koch, Jessica 2006. Economic Development and Ethnic Separatism in Western China: A New Model of Peripheral Nationalism. Murdoch University Asia Research Centre Working Paper 134 (August).

Lampton, David M. (ed.) 2001. The Making of Chinese Foreign and Security Policy in the Era of Reform, 1978-2000. Stanford: Stanford University Press.

Lardy, Nicholas R. 1998. China's Unfinished Economic Revolution. Washington, D.C.: Brookings Institution Press.

Lieberthal, Kenneth and David M. Lampton 1992. Bureaucracy, Politics, and Decision Making in Post-Mao China. Berkeley: University of California Press.

Lu, Ning 2000. The Dynamics of Foreign-Policy Decisionmaking in China, 2nd ed. Boulder, Colo.: Westview Press.

Matsushita, Mitso 2004. 'Legal Aspects of Free Trade Agreements: In The Context of Article XXIV of the GATT 1994.' In Mitso Matsushita and Dukgeun Ahn (eds) WTO and East Asia: New Perspectives, London: Cameron May: 497-514.

Mathis, James H. and Jagdish N. Bhagwati 2002. Regional Trade Agreements in the GATT/ WTO: Article XXIV and the Internal Trade Requirement. The Hague; Norwell, MA: T.M.C. Asser Press; Sold and distributed by Kluwer Law International.

Milner, Helen V., B. Peter Rosendorff and Edward D. Mansfield 2004. 'International Trade and Domestic Politics: The Domestic Sources of International Trade Agreements and Institutions.' In E. Benvenisti and M. Hirsch (eds). The Impact of International Law on International Cooperation: Theoretical Perspectives. New York: Cambridge University Press: 216-43.

MOFCOM. 2006. 'Director of the International Economic and Trade Relations Department Yu Jianhua talks about Free Trade Areas and Regional Economic Cooperation.' http:/ / www.mofcom.gov.cn/fangtan/061229.shtml (29 Dec.)

- 2007. 'Vice Minister Yi Xiaozhun talks about China's Choices and Achievements in Regional Economic Cooperation.' http://yixiaozhun.mofcom.gov.cn/aarticle/ speeches/200705/20070504725234.html (29 May).

Moneyhon, Matthew D. 2004. 'Taming China's 'Wild West': Ethnic Conflict in Xinjiang.' Peace, Conflict, and Development: An Interdisciplinary Journal 5, 5: 2-23.

Montinola, Gabriella, Yingyi Qian and Barry R. Weingast 1996. 'Federalism, Chinese Style: The Political Basis for Economic Success.' World Politics 48, 1: 50-81.

People's Daily (English) 2001. 'China Considering to Set Up Special Trade Area: Long Yongtu.' 29 Nov.

Ravenhill, John 2005. 'Regionalism.' In J. Ravenhill (ed.) Global Political Economy. New York: Oxford University Press: 116-47.

Reardon, Lawrence 2002. The Reluctant Dragon: Crisis Cycles in Chinese Foreign Economic Policy. Seattle and London: University of Washington Press.

Ren, Juntao 2006. 'Guangxi's Investment and Financing Measures in 'Two Corridors and One Circle' Cooperation.' Around Southeast Asia 5: 52-55.

Robinson, Thomas W. and David L. Shambaugh 1994. Chinese Foreign Policy: Theory and Practice. Oxford and New York: Clarendon Press; Oxford University Press.

Shambaugh, David 2002. 'China's International Relations Think Tanks: Evolving Struc- 
ture and Process.' The China Quarterly 171: 575-96.

Shang, Guoji 2005. 'China-ASEAN FTA's Experiment Field: The Early Harvest Program.' Available online at gjs.mofcom.gov.cn/accessory/200509/1127371793253.doc.

Shirk, Susan L. 1994. How China Opened Its Door: The Political Success of the PRC's Foreign Trade and Investment Reforms, Integrating National Economies. Washington, D.C.: Brookings Institution.

Tian, Kechuan 2006. 'Fine Wool Industry in China and the Free Trade between China and Australia.' The Australia-China FTA Agricultural Conference, Xi'an, 27 September.

Wan, Mingxu 2006. 'Guangxi's 'Access to ASEAN': Problems and Solutions.' Around Southeast Asia 2.

Wang, Shilu (ed.) 2006. 2005-2006 Dongnan Ya Baogao [Southeast Asia Report 2005-2006], Yunnan BlueBooks. Kunming: Yunnan University Press.

Woods, Lawrence T. 1993. Diplomacy and International Nongovernmental Organizations: A Study of the Pacific Economic Cooperation Movement. Vancouver: University of British Columbia Press.

WTO 2000. 'Synopsis of 'Systematic' Issues Related to Regional Trade Agreements.' 18(a), WT/REG/W/37 (Mar. 2).

$\mathrm{Xu}$, Changwen, Guanghui Li and Wei Li 2003. Zhongguo Lingpao Dongya Jingji Hezuo [China Leading the Race of East Asian Economic Cooperation]. Beijing: China Customs Press.

Yang, Dali 1996 'The Dynamics and Progress of Competitive Liberalization in China.' Issues \& Studies 32, 8: 195-208.

Zeng, Ka (ed.) 2007. China's Foreign Trade Policy: The New Constituencies. London and New York: Routledge.

Zhang, Yunling and Jianglin Zhao (eds) 2003. Yatai Quyu Hezuo De Fazhan [Developments of Asia Pacific Cooperation]. Beijing: World Affairs Press.

Zhang, Yunling and Xiaobing Zhou (eds) 2003. Dongya Hezuo De Jincheng Yu Qianjing [The Progress and Prospect of East Asian Cooperation]. Beijing: World Affairs Press.

Zweig, David 2002. 'Internationalizing China: Domestic Interests and Global Linkages,' Cornell Studies in Political Economy. Ithaca: Cornell University Press. 